\title{
The Plant Alkaloid Sanguinarine is a Potential Inhibitor of Follicular Angiogenesis
}

\author{
Giuseppina BASINI ${ }^{1}$, Suyen Eleonora SANTINI ${ }^{1)}$, Simona BUSSOLATI ${ }^{1)}$ and \\ Francesca GRASSELLI ${ }^{1}$ ) \\ ${ }^{1)}$ Department of Animal Production, Veterinary Biotechnology, Food Safety and Quality- \\ Veterinary Physiology, University of Parma, Parma, Italy
}

\begin{abstract}
Sanguinarine (SA), a phytobiotic from Sanguinaria Canadensis, has been demonstrated to inhibit vessel growth. Current restrictions on the use of antibiotic growth promoters have motivated addition of this alkaloid as a naturally appetizing feed additive for farm animals. However, concern may araise since angiogenesis is a fundamental event in ovarian follicle growth. Therefore, the aim of this study was to evaluate the potential negative role of SA in follicular angiogenesis. For this purpose, we studied the effect of $300 \mathrm{nM}$ SA on the production of vascular endothelial growth factor (VEGF) by swine granulosa cells from follicles $>5 \mathrm{~mm}$ and on the activation of Akt, the main effector of the VEGF signalling pathway. In addition, the potential interference of SA in vessel development was tested in an in vitro angiogenesis bioassay. SA inhibited both VEGF production and VEGFinduced Akt activation in swine granulosa cells. Moreover, it was able to block vessel growth induced by VEGF. Taken together, our results suggest that SA could be detrimental to follicular angiogenesis, and therefore supplementation of feed with this alkaloid should be carefully considered.

Key words: Akt, Angiogenesis, Granulosa cell, Pig, Sanguinarine, Vascular endothelial growth factor (VEGF)
\end{abstract}

(J. Reprod. Dev. 53: 573-579, 2007)

$\boldsymbol{S}^{a}$ anguinarine (SA; 13-methyl[1, 3]benzodioxolo[5, 6-c]-1,3-dioxolo[4,5-i]phenanthridinium) is derived from the root of Sanguinaria canadensis and other poppy-fumaria species [1]. SA has recently been proposed [2] as a natural appetizing feed additive for farm animals, as it possesses both a weight-gain stimulatory effect and antioxidant properties.

Integration of farm animal diets with plantderived compounds is becoming widespread. In fact, restrictions on the use of antibiotics, used in the past as probiotics, have greatly increased the interest in phytobiotics in livestock nutrition; however, little is known about the effects of these

Accepted for publication: January 12, 2007

Published online: February 19, 2007

Correspondence: G. Basini (e-mail: basini@unipr.it) molecules on different organic functions, such as reproductive efficiency.

In our previous work [3], our in vitro data indicated that SA exerts negative effects on swine granulosa cell features, and thus possibly interferes with female reproductive performance. Eun and Koh recently hypothesized that the antiangiogenic role of SA is possibly related to detrimental impact on fertility [4]. In fact, it is now well recognized that follicle growth is critically dependent on the genesis of new vessels [5]. Angiogenesis is mainly driven by vascular endothelial growth factor (VEGF) [6-8], which promotes endothelial cell mitosis, permeability, and survival [9]. The avascular granulosa cell layer represents the main component involved in VEGF production, at least in swine ovaries [10,11], and thus plays a role in the 
control of follicular angiogenesis. Activation of Akt/protein kinase B is a major pathway through which VEGF triggers the intracellular response [12]; Akt appears to be a key point of integration between VEGF signalling and other cell functions.

The aim of the current study was to investigate the role of SA in follicular angiogenesis. To do this, we evaluated the effect of SA on VEGF production and Akt activity in swine granulosa cells. The possible involvement of SA in the control of vessel development was verified in an in vitro angiogenesis bioassay [13] by studying its effects on VEGF-induced endothelial cell migration and sprouting.

\section{Materials and Methods}

All reagents were obtained from Sigma-Aldrich (St. Louis, MO, USA) unless otherwise specified.

\section{Granulosa cell isolation}

Swine ovaries were collected at a local abbatoir, placed into cold PBS (4 C) supplemented with penicillin (500 IU/ml) and streptomycin (500 $\mu \mathrm{g} /$ $\mathrm{ml})$, maintained in a freezer bag, and transported to the laboratory within $1 \mathrm{~h}$. The ovaries were washed twice with PBS, then with ethanol (70\%), and finally again with PBS at room temperature. The granulosa cells from follicles $>5 \mathrm{~mm}$ were aseptically harvested by aspiration with a 26-gauge needle and released into medium containing heparin $(50 \mathrm{IU} / \mathrm{ml})$. They were then centrifuged for pelleting and treated with $0.9 \%$ prewarmed ammonium chloride at $37 \mathrm{C}$ for $1 \mathrm{~min}$ to remove red blood cells. Cell number and viability $(85 \pm 2 \%$ mean \pm SEM) were estimated using a hemocytometer under a phase contrast microscope after vital staining of an aliquote of the cell suspension with trypan blue $(0.4 \%)$. The cells were cultured in culture medium (CM) composed of M199 supplemented with sodium bicarbonate (2.2 $\mathrm{mg} / \mathrm{ml})$, bovine serum albumin $(0.1 \%)$, penicillin (100 UI/ml), streptomycin $(100 \mu \mathrm{g} / \mathrm{ml})$, amphotericin B $(2.5 \mu \mathrm{g} / \mathrm{ml})$, selenium (5 ng/ml), and transferrin $(5 \mu \mathrm{g} / \mathrm{ml})$. Once seeded, they were incubated at $37 \mathrm{C}$ in a humidified atmosphere $(5 \%$ $\mathrm{CO}_{2}$ ) for $48 \mathrm{~h}$.

\section{VEGF production}

Granulosa cells were seeded at $10^{6}$ cells/well in 24-well plates in $1 \mathrm{ml} \mathrm{CM}+1 \%$ FCS and treated with sanguinarine $(300 \mathrm{nM})$. This concentration was chosen after preliminary experiments [3] documented the cytotoxic effect of SA at concentrations higher than $500 \mathrm{nM}$. The plates were incubated at $37 \mathrm{C}$ in a humidified atmosphere $\left(5 \% \mathrm{CO}_{2}\right)$ for $48 \mathrm{~h}$.

The VEGF content in the culture media was quantified by an ELISA (Quantikine; R\&D Systems, Minneapolis, MI, USA); this assay, which was developed for human VEGF detection, has been validated for pig VEGF [8]. The assay sensitivity was $0.23 \mathrm{pmol} / 1$, and the intra- and inter-assay CVs were always less than $7 \%$. A Spectra Shell microplate reader (SLT Spectra, Milan, Italy) set to read $450 \mathrm{~nm}$ emissions was used to quantify the reaction product. Data were corrected for the cellular protein concentration evaluated following detergent solubilization by means of a microplate assay using a DC Protein Assay Kit (Bio-Rad, Hercules, CA, USA) according to the manufacturer's instructions.

\section{Akt activity assay}

Cells were seeded at $10^{6}$ cells/well in eppendorf tubes in $1 \mathrm{ml} \mathrm{CM}$ and treated with sanguinarine (300 $\mathrm{nM}$ ) for $10 \mathrm{~min}$ at $21 \mathrm{C}$ in the presence or absence of VEGF (100 ng/ml; PeproTech EC, London, UK). After treatment, the cells were centrifuged for $10 \mathrm{~min}$ at $400 \times \mathrm{g}$. The supernatants were then discarded, and the cells were lysed by adding $1 \mathrm{ml}$ of lysis buffer (20 mM MOPS, $50 \mathrm{mM}$ $\beta$-glycerolphosphate, $50 \mathrm{mM}$ sodium fluoride, 1 $\mathrm{mM}$ sodium vanadate, $5 \mathrm{mM}$ EGTA, $2 \mathrm{mM}$ EDTA, 1\% NP40, $1 \mathrm{mM}$ dithiothreitol (DTT), $1 \mathrm{mM}$ benzamidine, $1 \mathrm{mM}$ PMSF, $10 \mu \mathrm{g} / \mathrm{ml}$ leupeptin and $10 \mu \mathrm{g} / \mathrm{ml}$ aprotinin) for $10 \mathrm{~min}$ on ice. The cell lysates were then centrifuged at $13,000 \times \mathrm{g}$ for 15 min. Clear supernatants were collected and stored at $-70 \mathrm{C}$ until assays were performed. Akt activity was evaluated using an Akt/PKB Kinase Activity Assay Kit (Stressgen, Victoria, Canada). This assay is based on a solid phase enzyme-linked immunoadsorbent assay (ELISA) that utilizes a synthetic peptide as a substrate for PKB and a polyclonal antibody that recognizes the phosphorylated form of the substrate. The assay is designed for analysis of PKB activity in the solution phase. The substrate, which is readily phosphorylated by $\mathrm{PKB}$, is precoated onto the wells of the provided PKB substrate microtiter plate. The 
samples to be assayed are added to the appropriate wells, and then ATP is added to initiate the reaction. The kinase reaction is terminated, and a phosphospecific substrate antibody that binds specifically to the phosphorylated peptide substrate is added to the wells. The phosphospecific antibody is subsequently bound by a peroxidase-conjugated secondary antibody. The assay is developed with tetramethylbenzidine substrate (TMB) and color develops in proportion to the PKB phosphotransferase activity. Color development is stopped with acid stop solution, and the intensity of the color is measured in a Spectra Shell microplate reader (SLi Spectro, Milan, Italy) at $450 \mathrm{~nm}$.

\section{Angiogenesis bioassay}

An immortalized porcine aortic endothelial cell line (AOC) [15] was generously provided by J. Yelamos (Hospital Universitario Virgen de la Arrixaca, Murcia, Spain). Choice of this line resulted from the unavailability of a porcine ovarian endothelial cell line. In all experiments, AOC cells at the $19^{\text {th }}$ passage were used, seeded in culture medium (CM) composed of M199 supplemented with sodium bicarbonate $(2.2 \mathrm{mg} /$ $\mathrm{ml})$, penicillin $(100 \mathrm{UI} / \mathrm{ml})$, streptomycin $(100 \mu \mathrm{g} /$ $\mathrm{ml})$, amphotericin B $(2.5 \mu \mathrm{g} / \mathrm{ml}), 20 \%$ fetal calf serum (Gibco, Grand Island, NY, USA), and incubated at $37 \mathrm{C}$ in a humidified atmosphere $(5 \%$ $\mathrm{CO}_{2}$ ). A microcarrier-based fibrin gel angiogenesis assay was performed as described by Grasselli et al. [13], with some modifications. Briefly, $12.5 \mathrm{mg}$ gelatin-coated cytodex-3 microcarriers in $1 \mathrm{ml}$ PBS were hydrated for $3 \mathrm{~h}$. After two washings in PBS and one in $\mathrm{CM}$, the microcarriers were put in flasks containing $5 \mathrm{ml} \mathrm{CM}$. AOC cells $\left(5 \times 10^{5}\right)$ were added and the microcarriers were cultured for $24 \mathrm{~h}$ in order to allow the endothelial cells to coat them. For the fibrin gel preparation, $40 \mu \mathrm{l}$ microcarriers covered with AOC cells were pipetted into 6-well plates containing a solution of fibrinogen $(1 \mathrm{mg} / \mathrm{ml}$ PBS, pH 7.6) and $1250 \mathrm{IU}$ thrombine $(250 \mu \mathrm{l})$. The fibrin gels were allowed to polymerize for $30 \mathrm{~min}$ at $37 \mathrm{C}$, and then they were equilibrated for $60 \mathrm{~min}$ with $2 \mathrm{ml} \mathrm{M199.} \mathrm{After} \mathrm{changing} \mathrm{the} \mathrm{medium,} \mathrm{the}$ AOC cells were treated with VEGF $(100 \mathrm{ng} / \mathrm{ml})$ in the presence or absence of sanguinarine (300 nM) and incubated at $37 \mathrm{C}$ in a humidified atmosphere $\left(5 \% \mathrm{CO}_{2}\right)$ for $48 \mathrm{~h}$. Endothelial cell proliferation in the fibrin gel matrix was evaluated by means of the

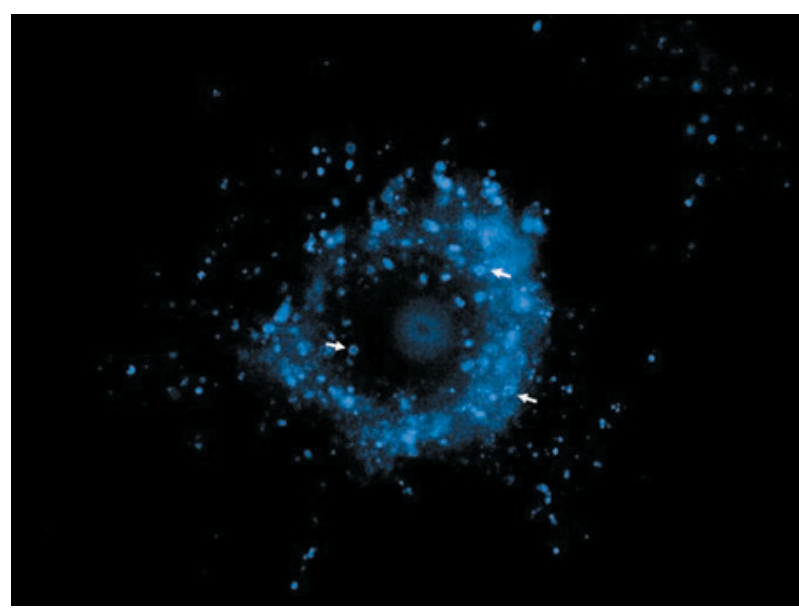

Fig. 1. A microcarrier covered by AOC cells stained by the nuclear dye bisbenzimide (Hoechst 33258) and examined using a fluorescence microscope. Arrows indicate early apoptotic cells.

public domain NIH Program Scion Image Beta 4.02 (Scion Corporation, MA, USA; http:// rsb.info.nih.gov/nih-image/). Ten pictures were taken for each gel at 48, 96, 144 and $192 \mathrm{~h}$. The images were converted into gray scale, resized to $50 \%$ (Paintbrush Software, MS Office), and saved in the 24-bit Bitmap format, which is compatible with Scion Image Beta 4.02. The modified images were then imported into the program, and measurements were performed by drawing the perimeter of the area occupied by the AOC cells ; the measurements were expressed as the number of pixels. In order to validate measurement of the area covered by AOC cells in the fibrin gels as a reliable method of evaluating cell proliferation, the fibrin gels were stained with the nuclear dye bisbenzimide (20 $\mu \mathrm{g} / \mathrm{ml}$, Hoechst 33258, in PBS) for 60 min and examined with a fluorescence microscope (Fig. 1). This procedure was performed 20 times. In each experiment, the number of nuclei was counted under a fluorescence microscope and pictures of the area covered by the AOC cells were taken in order to measure the surface covered in the fibrin gel. A strong correlation was observed between the area covered by AOC cells and the number of nuclei found in the same area $(r=0.96)$.

\section{Statistical analysis}

Data are expressed as means \pm SEM of six replicates/treatments repeated in five independent experiments. Statistical analysis was performed by 


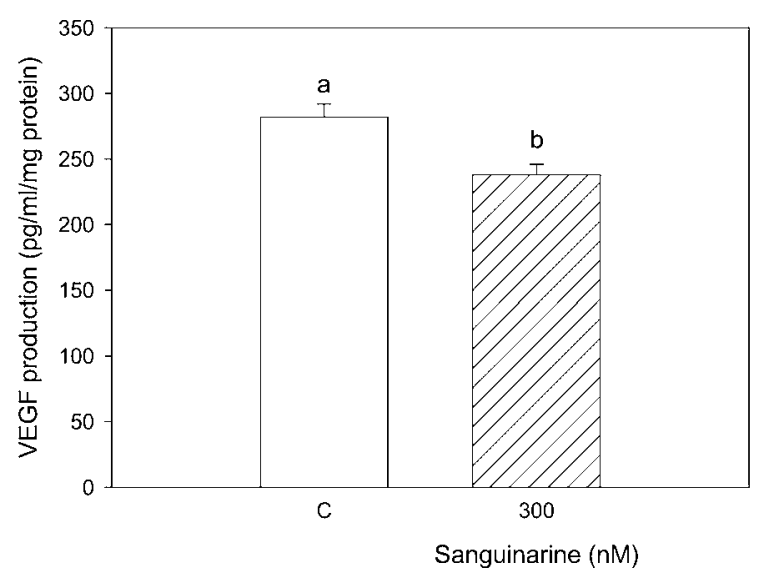

Fig. 2. Effect of the 48 h-treatment with SA ( $300 \mathrm{nM})$ on the VEGF production of swine granulosa cells. The data represent the mean \pm SEM of 6 replicates/treatments repeated in 5 different experiments. Different letters indicate significant differences $(\mathrm{P}<0.05)$ among treatments as calculated by ANOVA and Scheffé's $F$ test.

means of multifactorial ANOVA using the Statgraphics package (STSC, Rockville, MD, USA). When significant differences were found, the means were compared by Scheffe' $\mathrm{s} F$ test. P values of $<0.05$ were considered to be statistically significant.

\section{Results and Discussion}

Although organ vasculature is continuously developing and organizing during the neonatal and early postnatal periods, these processes are normally rare in the adult, except in pathological situations such as wound healing and inflammation. The mammalian ovary, however, has special properties such that it undergoes rapid cyclic remodeling throughout the reproductive cycle, which involves many tightly controlled cellular and hormonal events [16]. Angiogenesis, the formation of new capillaries from existing blood vessels, is a complex and fundamental process that occurs throughout follicular development and corpus luteum formation [17]. VEGF is a potent proangiogenic factor that interacts with its receptor, Flk-1/KDR and Flt-1, to stimulate angiogenesis in the follicle and corpus luteum [18]. VEGF is differentially expressed during follicular development, with reduced concentrations in the

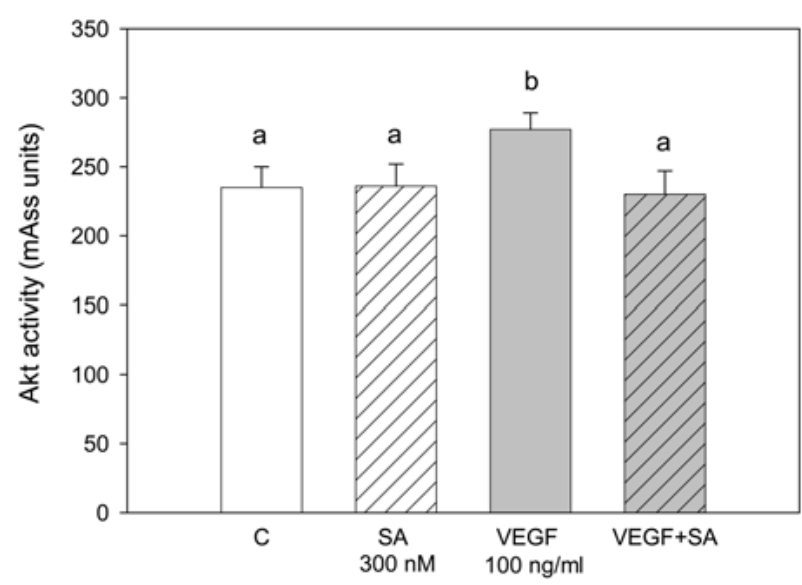

Fig. 3. Effect of the 48 h-treatment with SA (300 nM) in the presence or absence of VEGF $(100 \mathrm{ng} / \mathrm{ml})$ on Akt activity in swine granulosa cells. The data represent the mean \pm SEM of 6 replicates/treatments repeated in 5 different experiments. Different letters indicate significant differences $(\mathrm{P}<0.01)$ among treatments as calculated by ANOVA and Scheffé's $F$ test.

early phase of the cycle and increased levels as the follicle grows and develops [19]. Eun and Koh [4] indicated that the plant alkaloid sanguinarine (SA) potently suppresses angiogenesis both in vitro and in vivo. This novel antiangiogenic role should be taken into account since SA is a widely used phytogenic feed additive in pig nutrition [2] that possesses a wide range of biological activities, including growth-promoting effects in finishers [20] and antioxidant properties [21]. Phytobiotics are currently considered to be potential valuable alternatives to antiobiotic growth promoters that are being phased out or banned. Unfortunately, both their usefulness in enhancing feed conversion rate and their overall effect on animal health are awaiting final confirmation. The present work was undertaken to obtain a deeper insight into SA biological activity, focusing on possible interference with follicular angiogenesis. However, it should be noted that the possible impact on reproductive performance is strictly dependent on several factors including the biotransformation and disposition of SA. Our data suggests that SA may represent an antiangiogenic agent by inhibiting the VEGF secretion of granulosa cells. In fact, basal production $(1126 \pm 40 \mathrm{pg} / \mathrm{ml}$, mean \pm SEM) was significantly $(\mathrm{P}<0.05)$ reduced by treatment with 300 nM SA (Fig. 2).

To our knowledge, this is the first paper to report 

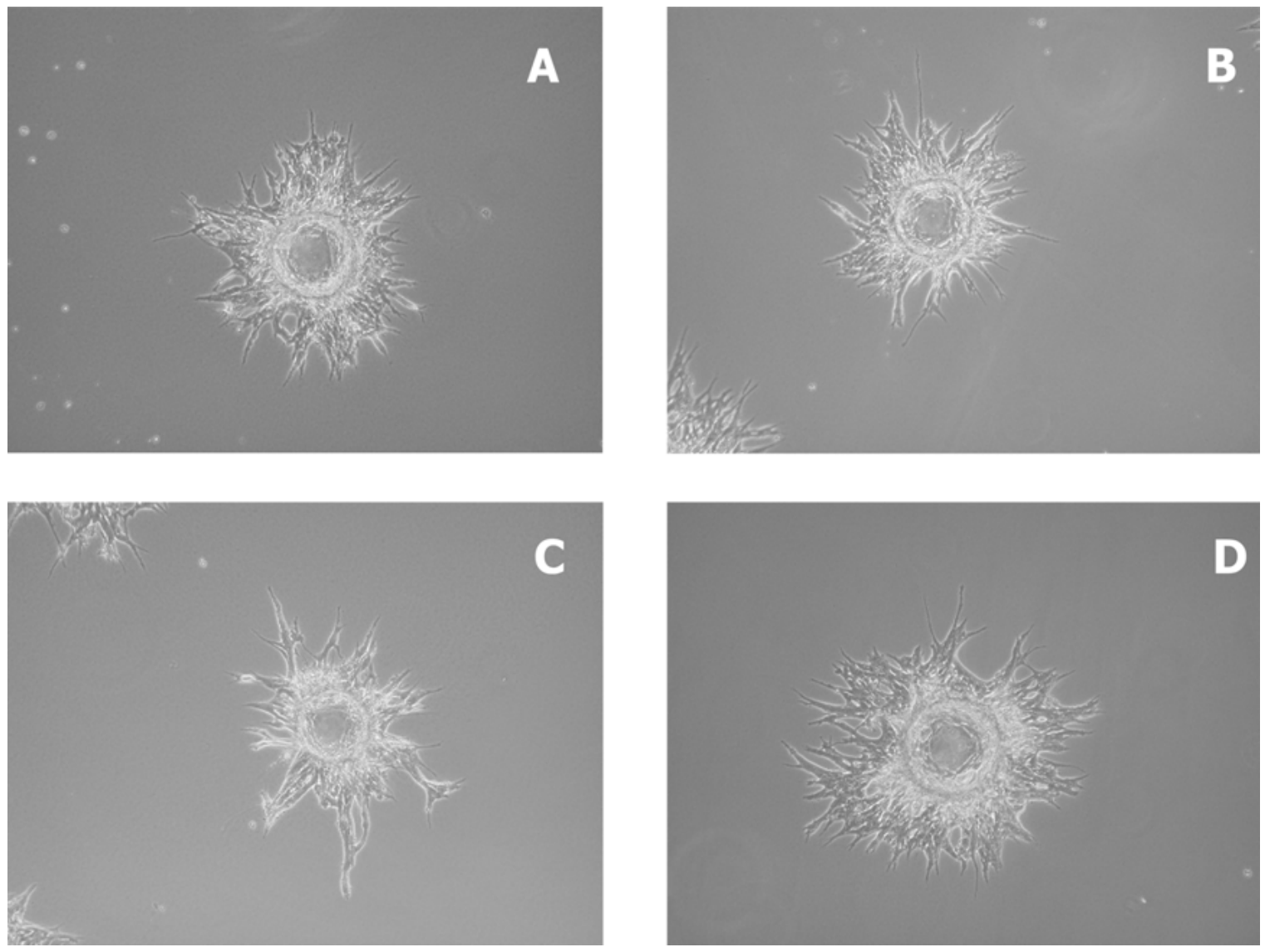

Fig. 4. Phase contrast micrographs showing AOC cell growth at $48 \mathrm{~h}$ in fibrin gel matrices. The cells were cultured in CM (A) and treated with SA (300 nM) (B) or VEGF $(100 \mathrm{ng} / \mathrm{ml})$ in the presence (C) or absence of SA (D).

Table 1. Effect of VEGF and SA on AOC cell growth

\begin{tabular}{cccc}
\hline Culture medium & VEGF & VEGF+SA & SA \\
\hline $7,981 \pm 407^{\mathrm{a}}$ & $12,510 \pm 812^{\mathrm{b}}$ & $8,159 \pm 332^{\mathrm{a}}$ & $7,021 \pm 503^{\mathrm{a}}$ \\
\hline
\end{tabular}

Values with different letters are significantly $(\mathrm{P}<0.001)$ different. The data represent the area covered by the AOC cells in fibrin gels (number of pixels).

a direct suppressive action of SA on VEGF production. Further study will be needed in order to clarify which VEGF isoform is affected by SA treatment. This effect, which could be beneficial in blocking cancer neovascularization [22], appears to be detrimental for ovarian physiology since development of an extensive vascular network represents a crucial event to guarantee proper growth and development of the antral follicle in ovulation.

In addition, our results emphasize that although SA has no effect on basal Akt activity, it does interfere with VEGF signal transduction mechanisms in granulosa cells by significantly blocking activation of Akt ( $\mathrm{P}<0.01$; Fig. 3$)$, the central effector in angiogenesis signaling [23]. These findings are in agreement with those of Eun and Koh [4], who demonstrated that SA exerts an antiangiogenic effect through blocking Akt activation in endothelial cells. In normal cells, protein kinases are involved in signals between cell membranes and the nucleus and regulation of progression through the cell cycle. Akt controls these processes by activating other messenger 
proteins that can influence the cell proliferation cycle. Many tumor cells possess protein kinases that are permanently turned on, forcing the cell into constant division. Numerous phytochemicals are reported to interfere with cell signaling and may counteract the adverse effects of protein kinase overactivity. In particular, inhibition of Akt has been found to suppress angiogenesis [24]. As already reported, suppression of VEGF-induced Akt activation could occur through blockage of VEGF-induced PI 3'-kinase Akt activation [4].

To further confirm the suppressive action of SA on blood vessel formation, we tested the effects of $\mathrm{SA}$ in a fibrin gel angiogenesis model [13]. A significant $(\mathrm{P}<0.001)$ increase of AOC cell growth was observed in the presence of VEGF. This effect was significantly $(\mathrm{P}<0.001)$ inhibited by the addition of SA. On the other hand, SA was incapable of inhibiting basal AOC cell proliferation (Fig. 4, Table 1).

Inhibition of VEGF-induced endothelial cell proliferation by SA would confirm that this substance can potentially suppress blood vessel formation in vivo [4] because VEGF is known to be a strong migration, sprouting, survival, and proliferation factor during angiogenesis [3, 23].

In summary, our study highlights a potential negative effect for SA on ovarian angiogenesis by interfering with different aspects of the angiogenic process the first of which is through inhibition of VEGF production by granulosa cells and reduction of the activation of Akt, the main effector of the VEGF signalling pathway in granulosa cells. Thereafter, we also showned that SA directly suppresses the proliferative effect of VEGF on endothelial cells. Collectively, the results of the present research suggest that SA can negatively affect female reproductive efficiency. Therefore, feed supplementation of livestock with this alkaloid should be carefully considered.

\section{Acknowledgements}

We would like to thank Dr. J. Yelamos (Department of Biochemistry, Molecular Biology and Immunology, Facultad de Medicina, Universidad de Murcia, Spain) for supplying the AOC. This research was supported by a MIUR PRIN grant.

\section{References}

1. Shamma M, Guinaudeau $\mathbf{H}$. Anorphinoid alkaloids. Nat Prod Rep 1986; 3: 345-351.

2. Kosina $P$, Walterova D, Ulrichova J, Lichnovsky V, Stiborova M, Rydlova H, Vicar J, Krecman V, Brabec MJ, Simanek V. Sanguinarine and chelerythrine: assessment of safety on pigs in ninety days feeding experiment. Food Chem Toxicol 2004; 42: 85-91.

3. Bianco F, Basini G, Grasselli F. The plant alkaloid Sanguinarine affects swine granulosa cell activity. Reprod Toxicol 2006; 21: 335-340.

4. Eun JP, Koh GY. Suppression of angiogenesis by the plant alkaloid, sanguinarine. Biochem Biophys Res Commun 2004; 317: 618-624.

5. Fraser HM, Wulff C. Angiogenesis in the primate ovary. Reprod Fertil Dev 2001; 13: 557-566.

6. Phillips HS, Hains J, Leung DW, Ferrara N. Vascular endothelial growth factor is expressed in rat corpus luteum. Endocrinology 1990; 127: 965-967.

7. Koos RD. Increased expression of vascular endothelial growth/permeability factor in the rat ovary following an ovulatory gonadotropin stimulus: potential roles in follicle rupture. Biol Reprod 1995; 52: 1426-1435.
8. Barboni B, Turriani M, Galeati G, Spinaci M, Bacci ML, Forni M, Mattioli M. Vascular endothelial growth factor production in growing pig antral follicles. Biol Reprod 2000; 63: 858-864.

9. Kim TE, Murren JR. Angiogenesis in non-small cell lung cancer: a new target for therapy. Am J Respir Med 2002; 1: 325-338.

10. Mattioli M, Barboni B, Turriani M, Galeati G, Zannoni A, Castellani G, Berardinelli P, Scapolo PA. Follicle activation involves vascular endothelial growth factor production and increased blood vessel extension. Biol Reprod 2001; 65: 1014-1019.

11. Basini G, Bianco F, Grasselli F, Tirelli M, Bussolati S, Tamanini C. The effects of reduced oxygen tension on swine granulosa cell. Regul Pept 2004; 120: 69-75.

12. Zachary I. VEGF signalling: integration and multitasking in endothelial cell biology. Biochem Soc Trans 2003; 31: 1171-1177.

13. Grasselli F, Basini G, Tirelli M, Cavalli V, Bussolati S, Tamanini C. Angiogenic activity of porcine granulosa cells co-cultured with endothelial cells in a microcarrier-based three-dimensional fibrin gel. J Physiol Pharmacol 2003; 54: 361-370. 
14. Carrillo A, Chamorro S, Rodriguez-Gago $\mathbf{M}$, Alvarez B, Molina MJ, Rodriguez-Barbosa JI, Sanchez A, Ramirez P, Munoz A, Dominguez J, Parrilla $\mathbf{P}$, Yelamos J. Isolation and characterization of immortalized porcine aortic endothelial cell lines. Vet Immunol Immunopathol 2002; 89: 91-98.

15. Conti M, Hsieh M, Park JY, Su YQ. Role of the EGF network in ovarian follicles. Mol Endocrinol 2006; 20: 715-723.

16. Geva E, Jaffe RB. Ovarian angiogenesis. In: Leung PCK, Adashi EY (eds.), The Ovary. Amsterdam: Elsevier Academic Press; 2004: 305-314.

17. Shimizu T, Jiang JY, Sasada H, Sato E. Changes of messenger RNA expression of angiogenic factors and related receptors during follicular development in gilts. Biol Reprod 2002; 67: 1846-1852.

18. Grasselli F, Basini G, Bussolati S, Tamanini C. Effects of VEGF and bFGF on proliferation and production of steroids and nitric oxide in porcine granulosa cells. Reprod Domest Anim 2002; 37: 362368.

19. Pederson A. Commercial products in feed for finishers: salocin, sangrovit, toyocerin and acid lac. The National Committee for Pig Production 1996; 341.

20. Vrba J, Kosina P, Ulrichova J, Modriansky M. Involvement of cytochrome P450 1A in sanguinarine detoxication. Toxicol Lett 2004; 151: 375-387.

21. Neri D, Bicknell R. Tumour vascular targeting. Nat Rev Cancer 2005; 5: 436-446.

22. Dimmeler S, Zeiher AM. Akt takes center stage in angiogenesis signaling. Circ Res 2000; 86: 4-5.

23. Yance DR, Sagar SM. Targeting angiogenesis with integrative cancer therapies. Integr Cancer Ther 2006; 5: 9-29. 